\title{
JUDICIAL REFORMS IN EASTERN EUROPE: ENSURING THE RIGHT TO A FAIR TRIAL OR AN ATTACK ON THE INDEPENDENCE OF THE JUDICIARY?
}

\author{
Olena Boryslavska \\ olenabor@gmail.com \\ https://orcid.org/0000-0001-8338-0966
}

Summary: 1. Introduction. The Right to a Fair Trial and Independence of the Judiciary. - 2. Elements of Judicial Independence. - 3. Judicial Reforms in Eastern Europe: General Overview. - 3.1 Serbia. - 3.2 Northern Macedonia. 3.3 Poland. - 3.4 Hungary. - 3.5 Romania. - 3.6 Moldova. - 3.7 Ukraine. - 4. Common Features of the Analysed Judicial Reforms in the Countries of Eastern Europe. - 5. Conclusions.

To cite this article: 0 Boryslavska 'Judicial Reforms in Eastern Europe: Ensuring the Right to a Fair Trial or an Attack on the Independence of the Judiciary?' 2021 1(9) Access to Justice in Eastern Europe 122-142. DOI: 10.33327/AJEE-18-4.1-a000049

To link to this article: https://doi.org/10.33327/AJEE-18-4.1-a000049

Submitted on 27 Jan 2020 / Revised 13 Feb 2021 / Approved 22 Feb 2021 / Published online: 01 Mar 2021 View data

Submit your article to Access to Justice in Eastern Europe http://ajee-journal.com/submissions

\section{ACKNOWLEDGEMENTS}

The author would like to express their gratitude to the reviewers for their help and to the English editor, Sarah White.

\section{CONFLICT OF INTEREST}

The author has declared that no conflict of interest or competing interests exist.

\section{CONTRIBUTOR}

The author contributed solely to the intellectual discussion underlying this paper, case-law exploration, writing and editing, and accepts responsibility for the content and interpretation.

Dr. Olena Boryslavska is a professor of the Department of Constitutional Law in Ivan Franko National University of Lviv (Ukraine), Member of the Commission on Legal Reform, created by the President of Ukraine (since 29 0ctober 2020). 


\title{
JUDICIAL REFORMS IN EASTERN EUROPE: ENSURING THE RIGHT TO A FAIR TRIAL OR AN ATTACK ON THE INDEPENDENCE OF THE JUDICIARY?
}

\author{
Boryslavska Olena \\ Doctor of Law, Professor of the Department of Constitutional Law, \\ Ivan Franko National University of Lviv, Ukraine
}

1

bstract The right to a fair trial is one of the essential elements of the rule of law - a fundamental value of the modern constitutional state. Among the systems of institutional, organisational, and substantive guarantees for ensuring this right, which stem from the

European Court of Human Rights case law, there is 'a fair and public hearing by an independent and impartial tribunal established by law'. This requirement is organically linked to the principle of the separation of powers, which is a central tenet of constitutionalism and provides for the functioning of the judiciary as a separate, independent branch of power. Therefore, any changes in the judicial systems of modern constitutional states, or, moreover, judicial reforms, should not only avoid contradicting these principles but, on the contrary, should be aimed at ensuring the right to a fair trial. However, the experience of such reforms in a number of Eastern European countries, despite the declaration of their perfectly legitimate and positive goals, raises questions about their true direction. As a result, not only does the institutional mechanism for the protection of human rights (which is the immediate goal of proclaiming the right to a fair trial) suffer, but also the constitutional systems of the countries concerned become unbalanced and unable to respond adequately to political challenges. This paper examines the essence of judicial reforms in a number of Eastern European countries (Serbia, Northern Macedonia, Poland, Hungary, Romania, Moldova, and Ukraine) and analyses them in terms of their impact on ensuring the right to a fair trial and the functioning of constitutional systems.

Keywords: judicial reform, the right to a fair trial, independence of the judiciary, separation of powers.

\section{INTRODUCTION. THE RIGHT TO A FAIR TRIAL AND INDEPENDENCE OF THE JUDICIARY}

The right to a fair trial reflected in Art. 6 of the Convention for the Protection of Human Rights and Fundamental Freedoms (ECHR) is one of the elements of the rule of law - a fundamental value of the modern constitutional state. ${ }^{1}$ It is inseparably connected

1 The term constitutional state has entered the scientific community of Ukraine relatively recently (various aspects of the constitutional state's functioning were analysed by P Stetsiuk, S Shevchuk, M Savchyn, S Riznyk, and others). However, it has been established in Western constitutional and legal doctrine for several centuries since the end of the 19th century, when the famous British scholar Albert Dicey, in his 'Introduction to the Study of the Law of the Constitution', not only distinguished states with constitutional and unconstitutional regimes, but also clarified the differences between certain types of constitutionalism, which later became the basis for singling out some models of constitutionalism. 
with human rights and democracy, which together constitute the threefold basis of the constitutional state and, at the same time, the value basis for European integration..$^{2}$ It is no coincidence that the European Court of Human Rights (ECtHR) highlights the 'hearing of a case by an independent and impartial tribunal established by law' within the developed system of institutional, organisational and substantive guarantees of the right to a fair trial. ${ }^{3}$

The role of the judiciary in constitutional states varies, but within the European (continental) model of constitutionalism ${ }^{4}$ (which is present in the countries examined in this study), the purpose of the judiciary is: first, guaranteeing and protecting fundamental rights; second, the abolition of illegal acts of executive bodies; third, protection against possible arbitrariness of investigative bodies (not all of them are part of the executive branch); fourth, recognition of laws as unconstitutional (if the constitutional jurisdiction is part of the judiciary), ensuring the inviolability of constitutional norms on guaranteeing human rights, the separation of powers, and other constitutional values and principles.

Undoubtedly, the most important mission of the judiciary is to protect the fundamental rights and freedoms of the individual. And in European countries, this role is special because it is associated with the operation of international human rights treaties, ${ }^{5}$ which are binding for the national legal systems of European states and impose appropriate responsibilities on public authorities (legislative, executive, and judicial). Along with the established international human rights protection mechanism, the role of the national judiciary is crucial in the protection of fundamental rights, as courts review the compliance of the national public authorities' activities with conventional norms, applying them directly. Herewith, national courts exercise the so-called 'diffuse convention control', protecting fundamental rights from violations by national governments on the basis of their own interpretation

The concept of a constitutional state is developed in various modern studies, such as: J Habermas, 'Civil disobedience: Litmus test for the democratic constitutional state' (1985) 30 Berkeley Journal of Sociology, 95$116<\mathrm{http}: / /$ www.jstor.org/stable/41035345> accessed 14 February 2021; A Sajo, 'Corruption, clientelism, and the future of the constitutional state in Eastern Europe' (1998) 37 E. Eur. Const. Rev., 37; R Myerson, 'The autocrat's credibility problem and foundations of the constitutional state' (2008) 102 (1) The American Political Science Review, 125-139 DOI:10.2307/27644502; Christian Joppke, Is multiculturalism dead?: Crisis and persistence in the constitutional state (Cambridge 2017); N Barber, The constitutional state (Oxford Scholarship Online: January 2011) DOI:10.1093/acprof:oso/9780199585014.001.0001; J Weinrib, 'The modern constitutional state' in Dimensions of dignity: The theory and practice of modern constitutional law, Cambridge Studies in Constitutional Law (Cambridge University Press 2016) DOI:10.1017/CBO9781316026663.005; D Gosewinkel, 'The constitutional state' in H Pihlajamäki, MD Dubber and M Godfrey (eds), The Oxford handbook of european legal history (Oxford University Press 2018) DOI: 10.1093/oxfordhb/9780198785521.013.42.

In this article, by constitutional state, we mean a non-arbitrary state with public authorities that is limited by constitutional means (including a written constitution) in order to ensure fundamental human rights.

2 Statute of the Council of Europe, London, 5.V.1949, preamble and articles 1, $3<$ https://rm.coe. int/1680306052>; Consolidated Version of the Treaty on European Union, Official Journal of the European Union, 9 May 2008, C 115/15.

3 Campbell and Fell $v$ The United Kingdom App no 7878/77 (ECtHR, 28 June 1984) para 78.

4 The issue of models of constitutionalism has been studied, in particular by J Couso, 'Models of democracy and models of constitutionalism: The case of Chile's constitutional court 1970-2010' (2011) Texas Law Review, 1517-1536; Luc B Tremblay, 'Two models of constitutionalism and the legitimacy of law: Dicey or Marshall?' (2006) 6 (1) Oxford University Commonwealth Law Journal, 77-101 DOI: 10.1080/14729342.2006.11421466); Stefan Gardbaum, 'Introduction' in The new commonwealth model of constitutionalism: Theory and practice, Cambridge Studies in Constitutional Law (Cambridge University Press 2013) DOI:10.1017/CBO9780511920806.001.

For more details on the nature and features of the European model of constitutionalism, as well as the role of the independence of the judiciary in it, see: O Boryslavska, Yevropeiska model konstytutsionalizmu: Systemno-aksiolohichnyi analiz (Kharkiv 2018) 244-260 [European Model of Constitutionalism: System and axiological analysis].

5 These include, in particular, the European Convention on Human Rights and the relevant case-law of the ECtHR, as well as EU legal acts and relevant case-law within the jurisdiction of the Court of Justice. 
of conventional norms, based on the conditions and peculiarities of a particular national legal order. ${ }^{6}$ International judicial bodies monitor the correctness of the application of the provisions of the Convention by national courts in cases of appeal to them by interested parties who believe that their fundamental rights are not protected by the state.

Thus, ensuring the right to a fair trial is a necessary condition for the reality (not the illusion) of fundamental rights (both constitutional and conventional), as well as for protection from state arbitrariness. Only an independent tribunal can carry out this mission, so the ECtHR has repeatedly emphasised the importance of judicial independence in its case-law on Art. 6 of the Convention, highlighting such aspects as independence from the executive and from case parties. Independence from the executive, according to the ECtHR, is determined by such factors as the procedure for appointing judges, the duration of their term of office, and guarantees against external pressure, as well as whether the court gives the impression of its independence. ${ }^{\text {? }}$

Judicial independence is interpreted by the Court in connection with the principle of separation of powers, which 'has assumed growing importance in the case-law of the Court, ${ }^{8}$ but the appointment of judges by the executive or the legislature is considered 'permissible, provided the appointees are free from influence or pressure when carrying out their adjudicatory role.' Equally important for guaranteeing the independence of the judiciary in the context of Art. 6, from the ECtHR's point of view, is the immutability of judges while performing their duties, which is seen as a prerequisite for their independence and a guarantee of the right to a fair trial. ${ }^{10}$

The importance of the right to a fair trial for human rights and the rule of law creates a number of requirements for states to ensure the independence of the judiciary. It is logical that these requirements should be taken into account in cases of judicial reforms. Moreover, it seems that the guarantee of the right to a fair trial should serve as a kind of guide for such reforms. However, the experience of a number of European countries shows that this is not always the case.

This paper presents analyses of the judicial reforms that have taken place over the last two decades in Eastern Europe in terms of their relationship to the institutional elements of the right to a fair trial and guarantees of judicial independence and seeks answers to the question posed in the title of the article.

\section{ELEMENTS OF JUDICIAL INDEPENDENCE}

Independence of the judiciary is considered a universal principle, recognised at the UN level and reflected in numerous international legal acts establishing relevant international standards. The most important among them are the Basic Principles on the Independence of The Judiciary, adopted by the United Nations General Assembly (1985), ${ }_{11}^{11}$ the Montreal Universal Declaration on the Independence of Justice, adopted at the final plenary session of the First

6 CDL-AD(2014)036, Report on the Implementation of International Human RIGHTS Treaties in Domestic Law and the Role of Courts, adopted by the Venice Commission at its 100th plenary session (Rome, 10-11 October 2014), Strasbourg, 8 December 2014 (pp. 4-5).

$7 \quad$ See, for example, cases Campbell and Fell $v$ The United Kingdom (n 4); Brudnicka and others $v$ Poland App no № 54723/00 (ECtHR,10 April 2018).

8 Stafford $v$ The United Kingdom [BП] App no 46295/99 (ECtHR, 28 May 2002) para 78.

$9 \quad$ Flux v Moldova App no 31001/03 (ECtHR, 3 July 2007) para 27.

10 Campbell and Fell $v$ The United Kingdom (n 4) para 80.

11 Basic Principles on the Independence of The Judiciary (General Assembly Resolutions 40/32 And 40/146). 
World Conference on the Independence of Justice (1983), ${ }^{12}$ and the Bangalore Principles of Judicial Conduct, adopted by the Economic and Social Council of the UN (2006). ${ }^{13}$

In addition, the Council of Europe has developed standards for the independence of the judiciary that must be ensured in the Member States. The Council of Europe's documents interpret the independence of the judiciary as 'the basic principle of the rule of law', and the aim of its implementation is to guarantee for every person the fundamental right to a fair trial only on a lawful basis and without any outside influence in accordance with Art. 6 of the ECHR. ${ }^{14}$

From the standpoint of the Council of Europe bodies, the independence of the judiciary is interrelated and interdependent with the independence of judges. Therefore, the Committee of the Council of Ministers recommended the governments of the Member States to take all necessary measures for enhancing the role of each individual judge and the judiciary as a whole and strengthening their independence and effectiveness. In particular, such responsibilities are vested in the executive and the legislature. ${ }^{15}$ It should be noted that the independence of judges is not considered as their 'prerogative or privilege granted in their own interests', but as a necessary tool to ensure the rule of law, which is introduced in the interests of those who rely on justice. At the same time, it is emphasised that independence must be guaranteed both from society as a whole and from specific parties in a case in which judges must make their judgments. ${ }^{16}$

The documents of the Council of Europe distinguish between the internal and external independence of judges. Internal independence means that each individual judge should be independent and impartial in the exercise of adjudicating functions and able to act without any restriction, improper influence, pressure, threat, or interference, direct or indirect, from any authority, including authorities internal to the judiciary. Additionally, the hierarchical judicial organisation should not undermine individual independence. ${ }^{17}$ The external independence of judges stems from the relationship within the system of state power, as well as the relationship between the judiciary and the society. Relations with the legislative and executive branches are important in ensuring the external independence of the judiciary. In addition to the fact that the legislative and executive branches are prohibited from reviewing court decisions (except for amnesty, pardon, or similar measures), the Council of Europe has developed standards for statutes that determine the status of judges. Such statutes should ensure the competence, independence, and impartiality of a judge that every person when applying to a court relies on and cannot make changes aimed at reducing the level of guarantees already achieved in the respective states. ${ }^{18}$ This provision is crucial from the point of view of this study because the law is usually the primary tool for judicial reform.

Important means of ensuring the internal (personal) independence of judges are the procedure for replacing judicial positions, the term of office, and prosecution of judges.

12 Montreal Universal Declaration on the Independence of Justice, adopted at the final plenary session of the First World Conference on the Independence of Justice held at Montreal (Quebec, Canada) on 10 June 1983.

13 The Bangalore Principles of Judicial Conduct, adopted by the Economic and Social Council of the UN, ECOSOC 2006/23.

14 Recommendation CM/Rec (2010)12 On judges: Independence, efficiency and responsibilities and explanatory memorandum (Adopted by the Committee of Ministers on 17 November 2010 at the 1098th meeting of the Ministers' Deputies).

Recommendation no R (94)12 Of the Committee of Ministers to Member States on the Independence, Efficiency and Role of Judges (Adopted by the Committee of Ministers on 13 October 1994 at the 518th meeting of the Ministers' Deputies). of Ministers of the Council of Europe on standards concerning the independence of the judiciary and the irremovability of judges.

17 Recommendation CM/Rec(2010)12 (n 15).

18 European Charter on the statute for judges, Council of Europe, DAJ/DOC (98) 23, 10 July 1998. 
The defining standard for obtaining the position of a judge is that all decisions concerning the professional career of judges should be based on objective criteria, and the selection and career of judges should be based on merit, having regard to qualifications, integrity, ability, and efficiency. ${ }^{19}$ Moreover, merit means not only legal knowledge, analytical skills, or academic achievements of candidates, but also certain character traits, communication skills, efficiency in making judgments, a sense of justice, etc. ${ }^{20}$

An important question in view of the above-mentioned criteria is the procedure for assessing the qualities of candidates in practice. The only requirement in the Council of Europe recommendations in this regard is the use of 'transparent procedures and good practice' in dealing with the appointment of judges. At the same time, their importance is emphasised in view of the creation of preconditions for public trust and perception of the judiciary, which is an important condition for the functioning of the judiciary in a constitutional state. ${ }^{21}$ As for the subjects and procedures for the appointment of judges, European standards in this area are based on the requirement of independence of the subjects from political bodies: parliament and government. Thus, the Council of Europe bodies prefer judicial councils (with the majority of judges or retired judges) as independent entities forming the staff of the judiciary but do not preclude the application of other systems of appointment. If constitutional provisions or traditions allow governments to appoint judges, transparent and independent procedures must be provided to ensure that judges are selected on the basis of the objective criteria above. At the same time, the parliament is not considered a proper subject for the appointment of judges, as there is a danger that political expediency may outweigh the objective preferences of the candidate. ${ }^{22}$ For example, in its Opinion on the draft Constitution of Serbia, the Venice Commission criticised the parliamentary method of electing judges, noting that involving parliament in judicial appointments leads to the unjustified politicisation of the process because the nature of such appointments is too discretionary and political expediency will naturally outweigh effective assessment of the qualities of candidates. ${ }^{23}$

An important means of ensuring a judge's personal independence is the term of his or her tenure. According to European standards, regardless of the method of appointment (election), judges must have a guaranteed term of office until the established retirement age or the expiration of a fixed term of office. ${ }^{24}$ Moreover, preference is given to a lifelong appointment until a judge reaches retirement age, as it is considered that such an approach is the least problematic in terms of ensuring the independence of judges. The Venice Commission, for example, has repeatedly criticised the appointment of judges for a limited period (probationary period) as contrary to the principle of immutability of judges and adversely affecting their independence and impartiality, as they may make judgments based on their future appointments. ${ }^{25}$

19 Recommendation no R(94)12 (n 16).

20 CDL-AD (2010)004, Report on the Independence of the Judicial System, Part I: The Independence of Judges, Adopted by the Venice Commission at its 82nd Plenary Session (Venice, 12-13 March 2010). <http://www.venice.coe.int/webforms/documents/default.aspx?pdffile=CDL-AD(2010)004-e> accessed 12 February 2021.

21 CDL-AD (2010)004, Report on the Independence of the Judicial System, Part I (n 21).

22 CDL (2015)004, Preliminary Opinion on the Draft Law on Amending the Law on the Judicial System and the Status of Judges of Ukraine, Strasbourg, 11 February 2015. <http://www.venice.coe.int/ webforms/documents/default.aspx?pdffile=CDL(2015)004-e $>$ accessed 12 February 2021.

23 CDL-AD(2007)004, Opinion on the Constitution of Serbia, adopted by the Commission at its 70th plenary session (Venice, 17-18 March 2007), Strasbourg, 19 March 2007. <http://www.venice.coe.int/ webforms/documents/default.aspx?pdffile=CDL-AD(2007)004-e $>$ accessed 12 February 2021.

24 Recommendation no R (94) 12 (n 16).

25 CDL-AD (2007)003, Opinion on the Draft Law on the Judiciary and the Draft Law on the Status of Judges of Ukraine, adopted by the Venice Commission at its 70th Plenary Session (Venice, 1617 March 2007), par. 26. <http://www.venice.coe.int/webforms/documents/default.aspx?pdffile=CDLAD(2007)003-e> accessed 12 February 2021.; CDL(2015)004, Preliminary Opinion on the Draft Law on Amending the Law on the Judicial System and the Status of Judges of Ukraine (n 23). 
No less important for ensuring the independence of the judiciary is the procedure for bringing judges to justice: both criminal and disciplinary. It should be mentioned that judicial immunity also includes protection against civil suits for 'actions done in good faith in the course of their functions ${ }^{26}$ Protection from illegal prosecution, as well as prosecution that aims to pressure the court, is provided by the institute of judicial immunity. Judicial immunity provides for a special procedure for prosecuting judges, which requires the consent of certain authorised entities for a judge's prosecution. In this regard, there are two key requirements: the first concerns the very existence of judicial immunity; the second stipulates that the consent to prosecute judges must be given by entities independent of politics (either courts or so-called judicial councils, in which judges constitute at least a majority). For example, the Venice Commission has repeatedly stressed the need to delegate the power of consenting to the prosecution of judges in Ukraine from parliament to the court ${ }^{27}$ or the High Council of Justice, which should be 'truly independent' and have a majority of judges. ${ }^{28}$

The question of the extent of judicial immunity is important. The bodies of the Council of Europe assume that judges should enjoy a certain degree of immunity, but that this should not be general immunity (as provided, for example, by the 1991 Bulgarian Constitution, which protected them against prosecution for criminal acts committed by them for which they should be answerable before the courts). ${ }^{29}$ Undoubtedly, judges must be protected from outside influence. To this end, they should enjoy functional immunity from prosecution for acts performed in the exercise of their functions, with the exception of intentional crimes, eg, taking bribes. ${ }^{30}$

In general, the requirements outlined here are designed to ensure the functioning of an effective and independent judiciary capable of impartially resolving conflicts that arise in the state and protecting human rights. However, factors that do not allow the judiciary to effectively perform its functions on these principles are corruption and, consequently, a low level of public confidence. The latter is the most common excuse used in the reasoning for providing judicial reforms. Such confrontation in practice influences the independence of the judiciary and, sometimes, outright attempts of political pressure on it while solving the problems of corruption, integrity, and public distrust, as a rule, also fails.

\section{JUDICIAL REFORMS IN EASTERN EUROPE: GENERAL OVERVIEW}

The significant number of standards and documents developed by the Council of Europe to guarantee the independence of the judiciary is not accidental. While in states with established traditions of democracy, the independence of the judiciary is generally guaranteed, in countries where these traditions are still being formed or restored after interruption by

26 CDL-AD (2003) 12, Memorandum Reform of the Judicial System in Bulgaria, Conclusions, adopted by the Venice Commission at its 55th plenary session (Venice, 13-14 June 2003), par. 15.a. <http://www.venice. coe.int/webforms/documents/default.aspx?pdffile=CDL-AD(2003)012-e > accessed 12 February 2021.

27 CDL-AD (2007)003, Opinion on the Draft Law on the Judiciary and the Draft Law on the Status of Judges of Ukraine (n 26).

28 CDL-AD (2011)033, Opinion on Proposals Amending the Draft Law on the Amendments to the Constitution to Strengthen the Independence of Judges of Ukraine, adopted by the Venice Commission at its 97th Plenary Session (Venice, 6-7 December 2013), par. 79. <http://www.venice.coe.int/webforms/ documents/CDL-AD(2011)033-e.aspx> accessed 12 February 2021. CDL-D(2013)034, Opinion on Proposals Amending the Draft Law on the Amendments to the Constitution to Strengthen the Independence of Judges of Ukraine, Adopted by the Venice Commission at its 97th Plenary Session (Venice, 6-7 December 2013), par. 25 <http://www.venice.coe.int/webforms/documents/default. aspx?pdffile=CDL-AD(2013)034-e $>$ accessed 12 February 2021.

29 CDL-AD (2003)12, Memorandum Reform of the Judicial System in Bulgaria, Conclusions (n 27).

30 CDL-AD (2010)004, Report On The Independence Of The Judicial System Part I (n 24) par. 61. 
socialist regimes, attempts to exert political influence on the judiciary are quite frequent and sometimes harsh and systematic. ${ }^{31}$ It is in the countries with young democracies, whose constitutional systems are in the process of constant transformation, that judicial reforms are quite often carried out. As we identified at the beginning of this study, these reforms should be primarily aimed at ensuring the right to a fair trial, improving access to justice, and, generally, ensuring more effective protection of human rights. It is this approach that corresponds to the common European constitutional values that have become the basis of European integration. ${ }^{32}$ The real situation in a number of countries is different. Yet, before drawing any general conclusions, a few practical examples of the judicial reform and their correlation with the principle of the independence of the judiciary should be analysed.

\subsection{Serbia}

Judicial reform in Serbia began with the adoption of the 2006 Constitution..$^{33}$ The same year, parliament ${ }^{34}$ approved the National Strategy for Judicial Reform, whose main objective was 'to restore public confidence in the judicial system of the Republic of Serbia by establishing the rule of law and legal certainty. ${ }^{35}$ The Strategy stated that it was based on 'four key principles: independence, transparency, accountability, and efficiency. ${ }^{36}$ Besides this, the document emphasises that 'the Government of the Republic of Serbia undertakes to implement the reform program to achieve a more effective, adequate and modern judiciary recognizing the right of Serbian citizens to access to justice and fair trial within reasonable timel by an impartial tribunal, ${ }^{37}$ namely, there is a reference to the right to a fair trial. In addition to the Constitution, Serbia adopted a Law on its implementation, which contained a number of controversial issues, including the reappointment of all judges who held office as of the entry into force of the new Constitution. Powers of reappointment of judges were vested in the High Council of Justice, which, although it was supposed to include six judges out of 11 members (ie, the majority), was nevertheless politically dependent on parliament, by which it was to be appointed.

The law was based on the principle of a discontinuity between the constitutional order under the previous Constitution and the one provided for in the 2006 Constitution, which ran counter to the constitutional process itself and took place in accordance with the procedure provided for in the previous Constitution. When analysing the content of the Law, the Venice Commission noted that the reasons, guided by the legislator, for anticipating the need for reappointment of judges were not obvious. If the desire was to 'get rid of judges who compromised themselves by cooperating with the previous regime or corruption, then reappointment was not the means to solve these problems, as it would not guarantee the appointment of the best judges. Therefore, such a decision would not seem 'wise. ${ }^{38}$

31 Resolution 2188 (2017), New threats to the rule of law in Council of Europe member States: selected examples, PACE // http://assembly.coe.int/nw/xml/XRef/Xref-XML2HTML-en.asp?fileid= 24214\&lang=en> accessed 12 February 2021.

32 O Mader, 'Enforcement of EU values as a political endeavour: Constitutional pluralism and value homogeneity in times of persistent challenges to the rule of law' (2019) 11 Hague J Rule Law, 133-170 DOI:10.1007/s40803-018-00083-x.

33 The Constitution replaced the previous 1990 Constitution following the break-up of the Union State of Serbia and Montenegro in 2006.

34 Serbian National Assembly.

35 Official website of the Ministry of Justice of Republic of Serbia, <https: arhiva.mpravde.gov.rs/en/ articles/judiciary/national-judicial-reform-strategy/> accessed 12 February 2021.

36 National Judicial Reform Strategy, Republic of Serbia Ministry of Justice p. 4, par. B, Key principles. <https: arhiva.mpravde.gov.rs/uploads/en/judiciary/national-judicial-reform-strategy/nationaljudicial-reform-strategy/Strategy.pdf $>$ accessed 12 February 2021.

37 Там само, pp. 3-4, par. A. Introduction.

38 CDL-AD(2007)004, Opinion on the Constitution of Serbia (n 24) par. 71-72. e 
The reappointment of judges by the politically dependent High Council of Justice can be considered an attempt of the parliamentary majority to exert political influence on the judiciary.

During 2008-2010, about 500 judges were reappointed (out of a total of 2,300 judges), about a third of the judges were not reappointed, and the remaining positions were taken by 'judicial elections' in 2011 and later. All this led to the blocking of the judicial system, which was unable to perform its functions. ${ }^{39}$ In addition, two decisions of the Constitutional Court of Serbia were issued in 2010, recognising the violation of the right to a fair trial in respect of judges who were not reappointed. About 100 applications were submitted to the ECtHR. As a result of these events in 2008-2009, Serbia dropped from 128th to 142nd place in the Judicial Independence Rating. ${ }^{40}$

In January 2012, the Parliamentary Assembly of the Council of Europe assessed the state of the Serbian judicial system negatively, noting the political influence of the parliament and the President on the judiciary. ${ }^{41}$ A 2014 World Bank analysis of Serbia's judiciary confirmed those inferences, noting that 'the judiciary remains plagued by corruption and is under the influence, and although some progress has been made, Serbia is generally lagging behind not only EU Member States but also its neighbours. ${ }^{42}$ As of January 2021, the official website of the Council of Europe contains information on the project 'Strengthening the Judicial Reform Process in Serbia, ${ }^{43}$ which was ongoing until 31 December 2020.

\subsection{Northern Macedonia}

Judicial reform in the Republic of Northern Macedonia has been ongoing since 2005 and has changed substantially under political and social influence. The constitutional amendments of 2005 provided for the creation of a new body - the Council of Justice - as an independent body of judicial self-government that was to deal with personnel and disciplinary issues in the judiciary. However, its functioning has shown a number of problems associated with cases of external influence on this body and the questionable effectiveness of its activities. ${ }^{44}$

Following the victory of the centre-right VMRO-DPMNE ${ }^{45}$ party in the 2006 parliamentary elections, the coalition declared the beginning of a radical judicial reform aimed at tackling corruption in the judiciary. The Laws on Courts and the Council of Justice adopted for this purpose became the basis for the mass dismissal of judges who had held office (from 2007 to 2014, the Council of Justice initiated 63 such procedures for judges, which is a significant number, taking into account the population of the country, and significantly exceeds the European statistics). ${ }^{46}$ After the 2014 parliamentary elections, the centrist-

39 V Beširević, “Governing without judges”: The politics of the Constitutional Court in Serbia' (2014) 12 (4) International Journal of Constitutional Law, 954-979 DOI:10.1093/icon/mou065.

40 Snapshot of the reappointment of judges in Serbia, Belgrade, Judges Association of Serbia, $2015<$ http://www. sudije.rs/files/Snapshot_of_the_reappointment_of_judges_in_Serbia.pdf > accessed 12 February 2021.

41 The honouring of obligations and commitments by Serbia, Resolution 1858 (2012) <http://assembly. coe.int/nw/xml/XRef/Xref-XML2HTML-en.asp?fileid=18065\&lang=en> accessed 12 February 2021.

42 Serbia Judicial Functional Review Executive Summary with Recommendations, Multi-Donor Trust Fund for Justice Sector Support in Serbia. October 2014, p. 4 <http://www.mdtfjss.org.rs/archive//file/Serbia\%20 JFR\%20-\%20Main\%20Findings\%20and\%20Recommendations.pdf > accessed 12 February 2021.

43 Council of Europe, European Committee's on Legal Cooperation website <https: www.coe.int/en/web/ cdcj/serbia-strengthening-the-judiciary-reform-process-in-serbia> accessed 12 February 2021.

44 D Preshova, I Damjanovski and Z Nechev, 'The Effectiveness of the European model of judicial independence in the Western Balkans: Judicial councils as a solution or a new cause of concern for judicial reforms' Center for the Law of EU External Relations, CLEER Papers 2017/1.

45 Internal Macedonian Revolutionary Organization - Democratic Party for Macedonian National Unity.

46 CDL-AD (2015)042, Opinion on the Laws on the Disciplinary Liability and Evaluation of Judges of 'The Former Yugoslav Republic of Macedonia', adopted by the Venice Commission at its 105th Plenary 
right coalition, which won a qualified majority, began constitutional reform, part of which was aimed at changing the composition of the Council of Justice. However, given the impossibility of completing the process of amending the Constitution (opposition parties challenged the election results and boycotted the work of parliament), the parliament passed the Law 'On the Council for Determination of the Facts and Initiation of Disciplinary Procedure for Establishing Disciplinary Responsibility of a Judge' (February 2015). This newly created body was given the right to initiate disciplinary proceedings against judges, ie, powers that, under the Constitution, belonged to the Council of Justice. Such steps were negatively assessed by the Venice Commission, as the newly created body actually duplicated the Council of Justice in its competence. ${ }^{47}$ Nevertheless, the Council was established, and a bill to eliminate it was only developed in 2017. ${ }^{48}$

In fact, in 2017, the government developed a Strategy for Reform of the Judicial Sector for the Period 2017-2022 with an Action Plan. In particular, it was stated that despite all the new legal projects and new institutions in the judicial sector and the incorporation of international standards and norms into the legal system, many problems remained. The results achieved in the field of judiciary efficiency 'remain overshadowed by its impaired independence, resulting in a low degree of quality and distrust of citizens in the institutions of the justice system. $^{\prime 49}$ The Strategy is designed for the period up to 2022, but its key provisions are on the verge of establishing European standards of judicial independence.

\subsection{Poland}

Serious problems with guaranteeing the independence of the judiciary have recently arisen in Poland. The ruling party, which has a majority in parliament and is represented by the President of the Republic, has attempted to establish political control over the judiciary (at the same time it blocked the activity of the Constitutional Tribunal, a body of constitutional jurisdiction). For this reason, the Law on the Organization of Ordinary Courts of 12 July 2017 was adopted, along with draft laws amending the Laws on the National Council of Justice and the Supreme Court establishing a new procedure for appointing judges - members of the Council. In its resolution, the Parliamentary Assembly of the Council of Europe called on the Polish authorities to refrain from carrying out this reform, as it poses a serious threat to the 'respect for the rule of law, in particular the independence of the judiciary' (para. 9.1).$^{50}$ Despite this, the bills were submitted to the Sejm by the President of the Republic of Poland, which caused a wave of outrage and protests in Polish society, as well as a negative reaction from the European Union and the Council of Europe.

During the judicial reform started in January 2017, a number of laws were passed by the Polish parliament. The most important of them were the acts on the General Courts (signed by the President and entered into force), the National Council of Justice, and the Supreme Court. The last two of these laws were vetoed by the President, who later introduced his

Session (Venice, 18-19 December 2015), Strasbourg, 21 December 2015, par. 6 <http: www.venice.coe. int/webforms/documents/default.aspx?pdffile=CDL-AD(2015)042-e > accessed 12 February 2021.

47 CDL-AD(2015)042, Opinion on the Laws on the Disciplinary Liability and Evaluation of Judges of 'The Former Yugoslav Republic of Macedonia' (n 48).

48 CDL-AD (2017)033, Opinion on the Draft Law on the Termination of the Validity of the Law on the Council for Establishment of Facts and Initiation of Proceedings for Determination of Accountability for Judges... <http: www.venice.coe.int/webforms/documents/default.aspx?pdffile=CDL-AD(2017)033-e> accessed12 February 2021.

49 Strategy for Reform of the Judicial Sector for the Period 2017-2022 with an Action Plan, Republic of Macedonia Ministry of Justice, p. $2<\mathrm{https} / / \mathrm{rm}$.coe.int/strategy-for-reform-of-the-judicial-sector-forthe-period-2017-2022-wi/16808c4384> accessed 12 February 2021.

50 Resolution 2188 (2017), New threats to the rule of law in Council of Europe member States: Selected examples, PACE <http://assembly.coe.int/nw/xml/XRef/Xref-XML2HTML-en.asp?fileid= 24214\&lang=en $>$ accessed 12 February 2021. 
version of the bills to the parliament. The key innovations of these legislative acts were the following: the right to appoint and dismiss chairmen of courts of general jurisdiction was given to the Minister of Justice; chairmen of the courts were given discretionary powers to distribute cases among judges ${ }^{51}$ the Minister of Justice was given the right to dismiss judges of the Supreme Court, and the President was given discretionary powers to extend the powers of a judge after he has reached the age limit; the right to appoint 15 members of the judiciary to the National Council of Justice passed to the Sejm, where at least three-fifths of its members must vote for such a decision (the total membership of the Council is 25 members, 15 of whom must be elected from among judges, six are elected by the parliament, one is appointed by the President, and three more are the members of this body ex officio). ${ }^{52}$ One of the measures of the judicial reform was reducing the age limit for judges from 70 to 65 years (this was done by the adoption of Laws on general courts and the Supreme Court). ${ }^{53}$ However, the European Court of Justice ordered Poland to remove this provision from the law and reinstate judges dismissed on its basis. ${ }^{54}$

It should be added that in 2016, the status of the Prosecutor General was also reformed, which resulted in the merger of the offices of the Prosecutor General and the Minister of Justice and a significant increase in the powers of the latter in the management of the prosecutorial system. ${ }^{55}$ Considering these new powers, the acquisition of the right to appoint staff in the judiciary indicates the excessive influence of the executive on the judiciary and the attempt to place it under control of the government and the parliamentary majority.

The purpose of the judicial reform, as it was announced in a public speech by the Minister of Justice, was 'to increase the efficiency of the judiciary, reduce delays in cases, strengthening the responsibility of judges, increase their professionalism, combat corporatism and restore public confidence in the judiciary. ${ }^{56}$ However, the analysis of the content of laws and drafts on judicial reform gives grounds to conclude that they were in their entirety aimed at establishing control of the executive branch (and through it, the parliamentary majority) over the courts. As the UN Special Rapporteur noted, taken together, these legislative acts pose a major threat to the independence of the Polish judiciary and the separation of powers. ${ }^{57}$ Serious reservations about the content of judicial reform have also arisen in European structures, which have emphasised the threats to the separation of powers, democracy, and the rule of law. ${ }^{58}$

51 As a rule, the distribution of cases is done via electronic lot, yet the system is run by the Ministry of Justice, and the matrix is not known to public.

52 CDL-AD(2017)031 Opinion on the Draft Act Amending the Act on the National Council of the Judiciary, on the Draft Act Amending the Act on the Supreme Court, Proposed by the President of Poland, and on the Act on the Organisation of Ordinary Courts, Strasbourg, 11 December 2017, <www.venice.coe.int/ webforms/documents/default.aspx?pdffile=CDL-AD(2017)031-e > accessed 12 February 2021.

53 Act on the Supreme Court of 8 December 2017 with amendments of 20 December 2019, Poland <https://www.venice.coe.int/webforms/documents/default.aspx?pdffile=CDL-REF(2020)005-e> accessed 12 February 2021.

54 Judgment of the ECJ in ECLI:EU:C:2019:924 <http://curia.europa.eu/juris/document/document.jsf? docid=219725\&doclang=EN> accessed 12 February 2021; Judgment in Case C-619/18 <http://curia. europa.eu/juris/d ocument/document.jsf?text=\&docid=207961\&pageIndex=0\&doclang=EN\&mode $=$ req\&dir $=\&$ occ $=$ first\&part $=1 \&$ cid $=2881539>$ accessed 12 February 2021.

55 CDL-AD(2017)028, Opinion on the Act on the Public Prosecutor's Office, as amended, para 20, Strasbourg, 11 December 2017 <www.venice.coe.int/webforms/documents/default.aspx?pdffile=CDLAD(2017)028-e> accessed 12 February 2021.

56 CDL-AD(2017)031, Opinion on the Draft Act Amending the Act on the National Council of the Judiciary (n 54).

57 Poland must safeguard judicial independence, UN Special Rapporteur <www.ohchr.org/EN/ NewsEvents/Pages/DisplayNews.aspx?NewsID=21912\&LangID=E $>$ accessed 12 February 2021.

58 European Parliament resolution of 13 April 2016 on the situation in Poland <http://www.europarl. europa.eu/sides/getDoc.do?type=TA\&reference $=$ P8-TA-2016-0123\&language $=\mathrm{EN}>$ accessed 12 February 2021.; European Parliament resolution of 14 September 2016 on the recent developments in 


\subsection{Hungary}

Hungary also faced serious problems in reforming the judiciary. After receiving an absolute majority in the 2010 parliamentary elections, Fidesz and its leader, Victor Orban, embarked on a comprehensive constitutional reform that affected the judiciary. Following the entry into force of the Basic Law, its transitional provisions, and the law on the legal status of judges, the mandatory retirement age for judges was reduced from 70 to 62 , which, according to the plan of the coalition, was to ensure a significant renewal of the judiciary. The Venice Commission stated in this regard that this measure was questionable in light of the fundamental principles and rules concerning the independence, status, and immutability of judges. According to various sources, this provision would cause approximately 300 of the most experienced judges to be obliged to resign within a year. Accordingly, about 300 vacancies would have to be filled. This could undermine the functioning of the courts and negatively affect the continuity and legal certainty, as well as open opportunities for undesirable influence on the composition of the judiciary..$^{59}$

It is worth noting that on 6 November 2012, the European Court of Justice ruled that such a radical reduction in the retirement age for Hungarian judges, as well as prosecutors and notaries, from 70 to 62 years of age was discriminatory on the grounds of age. In March 2013, the Hungarian Parliament passed a law amending the age limits in order to partially implement the judgments of the Constitutional Court of Hungary of 16 July 2012 and the judgment of the European Court of 6 November 2012..$^{60}$

Another means of influencing the judiciary was giving the President of the National Judicial Administration the power to transfer cases from one court to another in order to ensure that cases are heard within a reasonable period of time. In addition, the law does not establish objective regulatory criteria for the selection of cases to be transferred to another court. In such circumstances, the said discretion appears to be directed against the independence of the judiciary.

\subsection{Romania}

Overcoming corruption and restoring confidence in the judiciary were the main tasks of the reform of justice, which took place in several stages. The first was related to the European integration process and covered the period 2005-2009 (from the time of signing the Association Agreement with the EU). The main requirement that the country had to fulfil was to ensure the rule of law and overcome widespread corruption, ${ }^{61}$ which extended not only to the entire system of state power but also to the political system in general. Describing the outcome of this reform as of 2009, Martin Mendelski noted that there was 'considerable

Poland and their impact on fundamental rights as laid down in the Charter of Fundamental Rights of the European Union <http://www.europarl.europa.eu/sides/getDoc.do?type=TA\&reference=P8-TA-20160344\&language $=\mathrm{EN}>$ accessed 12 February 2021; European Parliament resolution of 15 November 2017 on the situation of the rule of law and democracy in Poland <www.europarl.europa.eu/sides/getDoc.do?t ype $=$ TA\&language $=$ EN\&reference $=$ P8-TA-2017-0442 $>$ accessed 12 February 2021.

59 CDL-AD(2012)001-e, Opinion on Act CLXII of 2011 on the Legal Status and Remuneration of Judges and Act CLXI of 2011 on the Organisation and Administration of Courts of Hungary, adopted by the Venice Commission at its 90th Plenary Session (Venice, 16-17 March 2012) <https://www.venice.coe. int/webforms/documents/CDL-AD(2012)001-e.aspx> accessed 12 February 2021.

60 European Parliament resolution of 3 July 2013 on the situation of fundamental rights: standards and practices in Hungary (pursuant to the European Parliament resolution of 16 February 2012). П. ВС. <http://www.europarl.europa.eu/sides/getDoc. do?pubRef=-//EP//TEXT+TA+P7-TA-20130315+0+DOC+XML+V0//EN> accessed 12 February 2021.

61 Elena Botezatu,, Regional cooperation in Central and Southeastern Europe: the Romanian experience in fighting corruption, European Institute of Romania, October $2006<$ https://mpra.ub.uni-muenchen. de/3163/> accessed 12 February 2021. 
change in the efficiency-related dimension (judicial capacity), leading to enhanced modernization of Romania's central judicial system. By contrast, there was persistence in the power-related dimension (judicial impartiality), undermining implementation and the achievement of de facto rule of law. ${ }^{62}$ It is worth noting that at this stage, the reform was based on the agreed position of the Ministry of Justice and the High Council of Magistracy (the highest body of judicial self-government) and was supported by the EU institutions. To implement the anti-corruption direction, a separate body with strong powers was established - the National Anti-Corruption Directorate - which has been successful for some years and has had some important results ${ }^{63}$ supported by Romanian society. As for the reform of the judiciary, it was primarily aimed at reducing the judicial workload, improving the organisational structure, increasing the budget, and so on.

The second phase of the reform came after 2017 when parliament passed laws reforming the justice system, which the European institutions criticised as threatening the independence of the judiciary. The adoption of these laws seems to have been considered in a broader context, given the general constitutional and political situation in the country since the 2012 constitutional crisis, the attempted constitutional reform of 2013, and the ongoing political turbulence. As stated in the yearly assessment report (under the EU Mechanism of Cooperation and Verification, established upon Romania's accession to the EU), 'within a nine months period since the January 2017 report, Romania has seen two governments, while growing tensions between State powers (Parliament, Government, and Judiciary) made the cooperation between them increasingly difficult. ${ }^{64}$

The aim of the reform, as it was defined by the government, was to provide answers to existing problems and needs of the judicial system and to adapt it to new social realities. For this purpose, three laws have been developed and adopted on the status of judges and prosecutors, on judicial organisation, and on the Superior Council of Magistracy. These laws were aimed at strengthening the independence of judges by separating judges' and prosecutors' careers but also at increasing the efficiency and accountability of the judiciary. Instead, they had the opposite effect, undermining the independence of Romanian judges and prosecutors and the public confidence in the judiciary. ${ }^{65}$ In particular, the laws provided for changing the procedure for appointing prosecutors, transferring a decisive influence on this process to the Minister of Justice, the limitation of freedom of expression of magistrates, and creating the new Section for investigating offences of magistrates, as well as the arrangements weakening the role of the Superior Council of Magistracy as the guarantor of the independence of the judiciary ${ }^{66}$

The adoption of these laws by the parliament has provoked mass public protests for anticorruption measures that have been ongoing for a long time. The adoption, in January 2017, of a Government Emergency Ordinance to decriminalise certain corruption offences caused

62 Martin Mendelski, Romanian rule of law reform: A two dimensional approach (Romania under Basescu 2011) 155-179.

63 European Commission, EU Anti-Corruption Report, Report from the Commission to the Council and the European Parliament, Brussels, 3 February 2014 COM(2014) 38 final <https://ec.europa.eu/homeaffairs/sites/homeaffairs/files/e-library/documents/policies/organized-crime-and-human-trafficking/ corruption/docs/acr_2014_en.pdf> accessed 12 February 2021.

64 Report from the Commission to the European parliament and the Council On Progress in Romania under the Cooperation and Verification Mechanism, Brussels, 15 November 2017 COM(2017) 751 final.

65 CDL-PI(2018)007, Opinion on draft amendments to Law No. 303/2004 on the statute of judges and prosecutors, Law No. 304/2004 on judicial organization, and Law No. 317/2004 on the Superior Council for Magistracy, par. $161<$ https://www.venice.coe.int/webforms/documents/default.aspx?pdffile=CDL$\mathrm{AD}(2018) 017$-e> accessed 12 February 2021.

66 CDL-AD(2018)017, Opinion on draft amendments to Law No 303/2004 on the statute of judges and prosecutors, Law No. 304/2004 on judicial organization, and Law No 317/2004 on the Superior Council for Magistracy, par. $162<$ https://www.venice.coe.int/webforms/documents/default.aspx?pdffile=CDL$\mathrm{AD}(2018) 017-\mathrm{e}>$ accessed 12 February 2021. 
widespread protests throughout Romania. In June-July 2018, the Romanian Parliament adopted amendments to the Criminal Code and the Criminal Procedure Code, ${ }^{67}$ which, according to the Venice Commission, will seriously impair the effectiveness of the Romanian criminal justice system in the fight against various forms of crime, including corruptionrelated offences. ${ }^{68}$ This again caused a wave of protests. The amendments to the abovementioned laws in February 2019 only strengthened their negative aspects in terms of violating the independence of judges. ${ }^{69}$

\subsection{Moldova}

Judicial reform in Moldova was launched in 2018 as an implementation measure of the National Action Plan for the Republic of Moldova - European Union Association Agreement for the period of 2017-2019. Relevant constitutional amendments were drafted in the same year but were not approved by the parliament in time (according to the Constitution of Moldova, if the parliament does not pass a bill amending the Constitution within a year, it is considered cancelled).$^{70}$ Therefore, the government has developed legislative amendments to the law on the Superior Council of Magistracy (SCM), which, according to the Constitution, consists of judges and university lecturers elected for a tenure of four years and three ex officio members - the President of the Supreme Court of Justice, the Minister of Justice, and the Prosecutor general. The proposed changes provide for increasing the number of members of the Council from 12 to 15 . The additional three members will include one judicial member and two lay members. Therefore, the SCM will be composed of seven judicial members (and seven substitutes) elected by the General Assembly of Judges and five lay members (who are tenured law professors) appointed by parliament, in addition to three ex officio members. The bill was passed by parliament in December 2019.

In addition, the process of drafting amendments to the Constitution, which have already been the subject of analysis by the Venice Commission, continues. In particular, it welcomed several positive features of the draft amendments: the removal of the probationary periods for judges, the limitations on the possibility for the President to reject proposals by the SCM in judicial appointments, the provision of only functional immunity for judges, the provision that at least half of the members of the SCM must be judges elected by their peers from among all court levels, the consultative role of the SCM in the preparation of the budget of the judiciary, and the statement at the constitutional level that the SCM is the guarantor of the independence of judicial authority, etc. ${ }^{71}$

Despite the generally positive direction and the corresponding positive assessment of these changes, their actual implementation in practice has raised a number of questions. In February 2020, the procedure of election of four lay members started (two positions remained vacant, and two new positions were created by the legislative amendments).

67 In total, about 300 changes were made.

68 CDL-AD(2018)021, Opinion on Amendments to the Criminal Code and the Criminal Procedure Code, adopted by the Venice Commission at its 116th Plenary Session (Venice, 19-20 October 2018) $<$ https://www.venice.coe.int/webforms/documents/default.aspx?pdffile=CDL-AD(2018)021-e> accessed 12 February 2021.

69 CDL-AD(2019)014, Opinion on Government Emergency Ordinance 7/2019 of 20 February 2019 on amendments to the three laws of justice in Romania (CDL-REF(2019)013<https://www.venice.coe.int/ webforms/documents/default.aspx?pdffile=CDL-AD(2019)014-e $>$ accessed 12 February 2021.

70 Constitution of the Republic of Moldova, art. 143(2) <https://www.presedinte.md/eng/constitution> accessed 12 February 2021.

71 CDL-AD(2020)015, Urgent Joint Opinion of the Venice Commission and the Directorate of Human Rights (DHR) of the Directorate Generale of Human Rights and Rule of Law (DGI) of the Council of Europe on the Draft Law on Amending the Law No 947/1996 on the Superior Council of Magistracy <https://www.venice. coe.int/webforms/documents/default.aspx?pdffile=CDL-AD(2020)015> accessed 12 February 2021. 
It is worth noting that in March, the composition of the parliament's standing committees, including the Legal Committee on appointments and immunities, was modified, and the parliamentary opposition left the Committee and boycotted the interview phase of the election of the lay members. Despite this, the parliament appointed four new members of the SCM from among law professors for a period of four years, without the votes of the MPs from the opposition. Moreover, in May, the law was amended again, introducing the possibility of filling vacancies for judicial members of the SCM with already-elected substitute members pending the convocation of the General Assembly of Judges. ${ }^{72}$ Such events questioned the absence of political influence, or at least its minimal character, on the formation of the SCM, which is clearly not conducive to restoring confidence in justice, the declared the goal of reform.

\subsection{Ukraine}

Changes in the judiciary took place during the entire period of Ukraine's independence. Initially, in 1990-1996, they were aimed at the introduction of universally recognised principles of justice and, after the adoption of the Constitution of Ukraine, the implementation of its provisions. However, full-scale judicial reform only began after 2014 as a result of the Revolution of Dignity.

The most important problem in the functioning of the judiciary in Ukraine so far has been the presence of political influence, which is incompatible with the principle of judicial independence. Thus, the Venice Commission recommended that Ukraine eliminate the role of political bodies in the appointment and dismissal of judges, the formation of courts, the composition of the High Council of Justice, the procedure for deprivation of judicial immunity, etc. (paragraph 14). ${ }^{73}$ In general, these requirements were taken into account in the reform of justice, which began in 2016 by amending the Constitution. As a result, the procedure for appointing judges was changed, as well as the composition of the High Council of Justice (created instead of the 'Vyscha Rada Justitciyi', which in English has the same translation - High Council of Justice), the majority of which, according to European standards, are judges, which received key personnel powers in the judiciary.

For their part, the public made serious allegations of corruption in the judiciary and insisted on its purification. Thus, in April 2014, the Law on Restoring Confidence in the Judiciary was adopted, which aimed to increase the authority of the judiciary by dismissing judges involved in court decisions that violated the constitutional rights and freedoms of citizens between 30 November 2013 and 23 February 2014. ${ }^{74}$ The law provided for three main things: 1) dismissal of court chairmen from administrative positions; 2 ) the termination of powers of members of the High Council of Justice (HCJ) and the High Qualification Commission of Judges (HQCJ); 3) the creation of a Temporary Special Commission for the Inspection of Judges, composed of 15 members (appointed by the plenum of the Supreme Court of Ukraine, the Government Commissioner for Anti-Corruption Policy, and the Verkhovna Rada of Ukraine - five members each). The inspection was carried out at the request of citizens, but the effectiveness of the Commission was very low. ${ }^{75}$

72 CDL-AD(2020)007, Joint Opinion of the Venice Commission and the Directorate General of Human Rights and Rule of Law (DGI) of the Council of Europe on the Revised Draft Provisions on Amending and Supplementing the Constitution with Respect to the Superior Council of Magistracy <https://www.venice. coe.int/webforms/documents/default.aspx?pdffile=CDL-AD(2020)007-e > accessed 12 February 2021. and the Status of Judges of Ukraine (n 23).

74 Law of Ukraine 'On Restoration of Confidence in the Judiciary in Ukraine' of 8 April $2014<$ https:// zakon.rada.gov.ua/laws/show/1188-18\#Text> accessed 12 February 2021.

75 Reports of the temporary commission <http://www.vru.gov.ua/add_text/30> accessed 12 February 2021. 
Almost simultaneously, the Law 'On Purification of Power' was adopted, which applied to all government officials, including judges. The subject of the judges' inspection under this law was the accuracy of the information on their property and its compliance with income received from legal sources during their tenure. Regarding the results of the procedures provided by law, it should be noted that in official sources, there is no complete information on the number of persons prosecuted, and the effectiveness of these procedures is questionable.

Significant changes in the justice system began with the introduction of amendments to the Constitution of Ukraine in 2016 and the adoption of a number of laws aimed at implementing constitutional reform. As a result, a new Supreme Court and the High Anti-Corruption Court were established (with the appointment of new judges on a competitive basis), a new composition of the High Council of Justice was formed, and a qualification assessment of judges was conducted. Along with the positive aspects of the reform, a number of problems arose of various levels of seriousness, including those related to the independence of the judiciary. Thus, the reform was aimed at replacing the staff of the judiciary (not open reappointment of judges). In the opinion of representatives of public organisations, this should lead to the purification of the judiciary from corruption and other negative phenomena. However, achieving this goal was accompanied by difficulties on the path of reform.

First of all, mass dismissals, which began in response to the established qualification assessment system, led to a critically insufficient number of current judges (in some courts, there were no judges at all for a long time). At the same time, the lack of a full HCJ and HQCJ for some time, as well as organisational difficulties in their work, did not allow this problem to be solved quickly. Regarding the activities of the HCJ and HQCJ, it also was not possible to eliminate the political influence on the formation and activity of these bodies. The HCJ enjoys a low level of trust from both society and the legal community, which accuses it of making politically motivated decisions.

These problems remain unresolved, which, on the one hand, does not contribute to the proper functioning of the judiciary and tangible progress towards guaranteeing the rule of law, and, on the other, is the reason each subsequent political power launches new 'judicial reforms. ${ }^{76}$

\section{COMMON FEATURES OF THE ANALYSED JUDICIAL REFORMS IN THE COUNTRIES OF EASTERN EUROPE}

This analysis of a number of judicial reforms in Eastern Europe provides grounds for distinguishing some of their common features. First of all, it should be emphasised that in almost all countries, judicial reforms have been the subject of sharp political battles, the content and course of which raises questions about their true purpose: is it really to guarantee the right to a fair trial, rather than establishing control (less or more) over the judiciary? In almost all the analysed countries, the objectives of the reform were to ensure the rule of law, the right to justice, to combat corruption, and to restore confidence in the judiciary. In addition, all the countries have declared that one of the key principles of reform is to respect (or ensure) the independence of the judiciary. However, practice has shown that the independence of the judiciary is the most vulnerable point in reform.

Ensuring the independence of the judiciary is of particular importance in new democracies. According to the Venice Commission, in old democracies, the decisive influence of the

76 In particular, in an interview with tThe New York Times on 19 December 2020, the President of Ukraine, V Zelensky, announced the 'beginning of a global reform of the judiciary' in 2021 ('With Trump Fading, Ukraine's President Looks to a Reset With the U.S. ', The New York Times, 19 December 2020). 
executive on the appointment of judges generally satisfies the requirement to guarantee the independence of the judiciary, as these powers are constrained by 'a long-established legal culture and traditions'. However, in new democracies (which have not yet developed traditions that could prevent the abuse of power), clear constitutional and legislative provisions are needed to prevent political abuse in the appointment of judges. ${ }^{77}$

The most problematic factors in terms of compatibility with the principle of independence of the judiciary were the means used in the reform, such as: the anticipatory dismissal of judges appointed for life; the reduction of the retirement age for judges, which led to a significant reduction in the number of current judges in the judiciary; the resolution of personnel issues and issues of disciplinary responsibility of judges by the executive body; the formation of bodies of personnel and disciplinary support of the judiciary by a political body (parliament, government) or under their significant or decisive influence.

In a number of countries, there have been attempts to make judicial reforms radical. However, such radical reforms involving the dismissal or reappointment of all or most judges (due to loss of 'public trust', suspicions of corruption, etc.) have not been successful and have clearly had no chance of success because they were in sharp opposition to established constitutional principles.

When conducting judicial reform, it should be taken into account that the judiciary is one of the branches of government that functions as a triad and is an integral part of the constitutional system. In addition, a single branch of government should not be demonised by accusing it of corruption, as this is a deliberate omission of or disregard for the general problem of the constitutional and political system. Therefore, anti-corruption reform is not identical to judicial reform and requires a systematic approach.

\section{Conclusions}

Both corruption and violations of the independence of the judiciary are equally threatening to the rule of law and the protection of human rights. Therefore, attempts to sacrifice at least one of these aspects in the course of judicial reform ultimately lead to negative consequences. The independence of the judiciary is an obligatory feature in the conditions of the constitutional state. It is impossible for the state to perform its functions to protect human rights and freedoms and the rights and interests of legal entities, control the legality and constitutionality of public authorities' activities, and guarantee the system of separation of state powers in general in cases of political or other pressure on judges. It is clear that political influence on the judiciary seriously upsets the balance in constitutional systems of government because, in this case, there is a kind of skew towards the legislature, executive, or excessive concentration of power by a political party that has a majority in parliament and controls the government. On the other hand, corruption is not only the cause of the ineffectiveness of the human rights protection system but also a factor that significantly distances a country from the rule of law and poses a threat to national security.

However, radical actions (in the form of a complete reset of the judiciary, reappointment or dismissal of all judges, early retirement, etc.), which look tempting in terms of opportunities to achieve results quickly, do not have a positive long-term result in practice, which is confirmed by the experience of a number of countries. Conversely, the lack of decisive action

77 CDL-AD(2007)028, Judicial Appointments Report adopted by the Venice Commission at its 70th Plenary Session (Venice, 16-17 March 2007), Venice, 22 June 2007 <http://www.venice.coe.int/ webforms/documents/default.aspx?pdffile=CDL-AD(2007)028-e > accessed 12 February 2021. 
by governments to find a compromise with corrupt institutions also fails. Therefore, the solution seems to be based on a balanced approach - a well-thought-out, systematic set of measures aimed at improving the justice system and resolutely overcoming corruption risks based on respect for basic constitutional principles.

The importance of the judiciary for the functioning of constitutional democracy can be described as existential. A corrupt judiciary, deprived of public trust, is one of the greatest threats to constitutional democracy and the biggest obstacle in developing countries. However, radical, unreasoned, unconstitutional measures aimed at carrying out judicial reforms not only do not bring the necessary and desired results but also move the state even further from constitutional democracy.

\section{REFERENCES}

Habermas J, 'Civil disobedience: Litmus test for the democratic constitutional state' (1985) 30 Berkeley Journal of Sociology, 95-116 <http://www.jstor.org/stable/41035345> accessed 14 February 2021.

Sajo A, 'Corruption, clientelism, and the future of the constitutional state in Eastern Europe' (1998) 37 E. Eur. Const. Rev., 37.

Myerson R, 'The autocrat's credibility problem and foundations of the constitutional state' (2008) 102 (1) The American Political Science Review, 125-139 DOI:10.2307/27644502.

Joppke Ch, Is multiculturalism dead?: Crisis and persistence in the constitutional state (Cambridge 2017).

Barber N, The constitutional state (Oxford Scholarship Online: January 2011) DOI:10.1093/acprof:o so/9780199585014.001.0001.

Weinrib J, 'The modern constitutional state' in Dimensions of dignity: The theory and practice of modern constitutional law, Cambridge Studies in Constitutional Law (Cambridge University Press 2016) DOI:10.1017/CBO9781316026663.005.

Gosewinkel D, 'The constitutional state' in Heikki Pihlajamäki, Markus D Dubber and Mark Godfrey (eds), The Oxford handbook of european legal history (Oxford University Press 2018) DOI: 10.1093/ oxfordhb/9780198785521.013.42.

Statute of the Council of Europe, London, 5.V.1949, preamble and articles 1, $3<$ https://rm.coe. int/1680306052> accessed 12 February 2021.

Consolidated Version of the Treaty on European Union, Official Journal of the European Union, 9 May 2008, C 115/15.

Couso J, 'Models of democracy and models of constitutionalism: The case of Chile's constitutional court 1970-2010' (2011) Texas Law Review, 1517-1536

Tremblay LB, 'Two models of constitutionalism and the legitimacy of law: Dicey or Marshall?' (2006) 6

(1) Oxford University Commonwealth Law Journal, 77-101 DOI: 10.1080/14729342.2006.11421466.

Gardbaum S, 'Introduction' in The new commonwealth model of constitutionalism: Theory and practice, Cambridge Studies in Constitutional Law (Cambridge University Press 2013) DOI:10.1017/ CBO9780511920806.001.

Boryslavska O, Yevropeiska model konstytutsionalizmu: Systemno-aksiolohichnyi analiz (Kharkiv 2018) 244-260

CDL-AD(2014)036, Report on the Implementation of International Human Rights Treaties in Domestic Law and the Role of Courts, adopted by the Venice Commission at its 100th plenary session (Rome, 10-11 October 2014), Strasbourg, 8 December 2014 (pp. 4-5).

Basic Principles on the Independence of The Judiciary (General Assembly Resolutions 40/32 And 40/146). 
Montreal Universal Declaration on the Independence of Justice, adopted at the final plenary session of the First World Conference on the Independence of Justice held at Montreal (Quebec, Canada) on 10 June 1983.

The Bangalore Principles of Judicial Conduct, adopted by the Economic and Social Council of the UN, ECOSOC 2006/23.

Recommendation $C M / \operatorname{Rec}(2010) 12$ On judges: Independence, efficiency and responsibilities and explanatory memorandum (Adopted by the Committee of Ministers on 17 November 2010 at the 1098th meeting of the Ministers' Deputies).

Recommendation No R(94)12 Of the Committee of Ministers to Member States on the Independence, Efficiency and Role of Judges (Adopted by the Committee of Ministers on 13 October 1994 at the 518th meeting of the Ministers' Deputies).

Opinion No 1 (2001) of the Consultative Council of European Judges for the attention of the Committee of Ministers of the Council of Europe on standards concerning the independence of the judiciary and the irremovability of judges.

European Charter on the statute for judges, Council of Europe, DAJ/DOC (98) 23, 10 July 1998.

CDL-AD(2010)004, Report on the Independence of the Judicial System, Part I: The Independence of Judges, Adopted by the Venice Commission at its 82nd Plenary Session (Venice, 12-13 March 2010). <http://www.venice.coe.int/webforms/documents/default.aspx?pdffile=CDL-AD(2010)004-e> accessed 12 February 2021.

CDL(2015)004, Preliminary Opinion on the Draft Law on Amending the Law on the Judicial System and the Status of Judges of Ukraine, Strasbourg, 11 February 2015. <http://www.venice.coe.int/ webforms/documents/default.aspx?pdffile=CDL(2015)004-e > accessed 12 February 2021.

CDL-AD(2007)004, Opinion on the Constitution of Serbia, adopted by the Commission at its 70th plenary session (Venice, 17-18 March 2007), Strasbourg, 19 March 2007. <http://www.venice.coe. int/webforms/documents/default.aspx?pdffile=CDL-AD(2007)004-e $>$ accessed 12 February 2021.

CDL-AD(2007)003, Opinion on the Draft Law on the Judiciary and the Draft Law on the Status of Judges of Ukraine, adopted by the Venice Commission at its 70th Plenary Session (Venice, 16-17 March 2007), para 26. <http://www.venice.coe.int/webforms/documents/default.aspx?pdffile= CDL-AD(2007)003-e> accessed 12 February 2021.

CDL-AD(2003)12, Memorandum Reform of the Judicial System in Bulgaria, Conclusions, adopted by the Venice Commission at its 55th plenary session (Venice, 13-14 June 2003), para 15.a. <http:// www.venice.coe.int/webforms/documents/default.aspx?pdffile $=C D L-A D(2003) 012$-e $>$ accessed 12 February 2021.

CDL-AD(2011)033, Opinion on Proposals Amending the Draft Law on the Amendments to the Constitution to Strengthen the Independence of Judges of Ukraine, adopted by the Venice Commission at its 97th Plenary Session (Venice, 6-7 December 2013), para 79. <http://www.venice. coe.int/webforms/documents/CDL-AD(2011)033-e.aspx> accessed 12 February 2021

CDL-D(2013)034, Opinion on Proposals Amending the Draft Law on the Amendments to the Constitution to Strengthen the Independence of Judges of Ukraine, Adopted by the Venice Commission at its 97th Plenary Session (Venice, 6-7 December 2013), para $25<$ http://www.venice.coe.int/webforms/ documents/default.aspx?pdffile=CDL-AD(2013)034-e $>$ accessed 12 February 2021.

Resolution 2188 (2017), New threats to the rule of law in Council of Europe member States: selected examples, PACE <http://assembly.coe.int/nw/xml/XRef/Xref-XML2HTML-en. asp?fileid=24214\&lang=en $>$ accessed 12 February 2021.

O Mader, 'Enforcement of EU values as a political endeavour: Constitutional pluralism and value homogeneity in times of persistent challenges to the rule of law' (2019) 11 Hague J Rule Law, 133170 DOI:10.1007/s40803-018-00083-x.

Official website of the Ministry of Justice of Republic of Serbia, <https: arhiva.mpravde.gov.rs/en/ articles/judiciary/national-judicial-reform-strategy/> accessed 12 February 2021.

National Judicial Reform Strategy, Republic of Serbia Ministry of Justice p. 4, para B, Key principles. <https: arhiva.mpravde.gov.rs/uploads/en/judiciary/national-judicial-reform-strategy/nationaljudicial-reform-strategy/Strategy.pdf > accessed 12 February 2021. 
Beširević V, "'Governing without judges": The politics of the Constitutional Court in Serbia' (2014) 12 (4) International Journal of Constitutional Law, 954-979 DOI:10.1093/icon/mou065

The honouring of obligations and commitments by Serbia, Resolution 1858 (2012) <http://assembly. coe.int/nw/xml/XRef/Xref-XML2HTML-en.asp?fileid=18065\&lang=en> accessed 12 February 2021.

Serbia Judicial Functional Review Executive Summary with Recommendations, Multi-Donor Trust Fund for Justice Sector Support in Serbia. October 2014, p. 4 <http://www.mdtfjss.org.rs/archive// file/Serbia\%20JFR\%20-\%20Main\%20Findings\%20and\%20Recommendations.pdf> accessed 12 February 2021.

Council of Europe, European Committee's on Legal Cooperation website <https: www.coe.int/ en/web/cdcj/serbia-strengthening-the-judiciary-reform-process-in-serbia> accessed 12 February 2021.

Preshova D, Damjanovski I and Nechev Z, 'The Effectiveness of the European model of judicial independence in the Western Balkans: Judicial councils as a solution or a new cause of concern for judicial reforms' Center for the Law of EU External Relations, CLEER Papers 2017/1.

CDL-AD(2015)042, Opinion on the Laws on the Disciplinary Liability and Evaluation of Judges of 'The Former Yugoslav Republic of Macedonia', adopted by the Venice Commission at its 105th Plenary Session (Venice, 18-19 December 2015), Strasbourg, 21 December 2015, para 6 <http: www.venice.coe.int/webforms/documents/default.aspx?pdffile $=C D L-A D(2015) 042-e>$ accessed 12 February 2021.

CDL-AD(2017)033, Opinion on the Draft Law on the Termination of the Validity of the Law on the Council for Establishment of Facts and Initiation of Proceedings for Determination of Accountability for Judges... <http: www.venice.coe.int/webforms/documents/default.aspx?pdffile=CDLAD(2017)033-e> accessed 12 February 2021.

Strategy for Reform of the Judicial Sector for the Period 2017-2022 with an Action Plan, Republic of Macedonia Ministry of Justice, p. 2 <https://rm.coe.int/strategy-for-reform-of-the-judicial-sectorfor-the-period-2017-2022-wi/16808c4384> accessed 12 February 2021.

CDL-AD(2017)031 Opinion on the Draft Act Amending the Act on the National Council of the Judiciary, on the Draft Act Amending the Act on the Supreme Court, Proposed by the President of Poland, and on the Act on the Organisation of Ordinary Courts, Strasbourg, 11 December 2017, $<$ www.venice.coe.int/webforms/documents/default.aspx?pdffile=CDL-AD(2017)031-e $>$ accessed 12 February 2021.

Act on the Supreme Court of 8 December 2017 with amendments of 20 December 2019, Poland <https://www.venice.coe.int/webforms/documents/default.aspx?pdffile=CDL-REF(2020)005-e> accessed 12 February 2021.

CDL-AD(2017)028, Opinion on the Act on the Public Prosecutor's Office, as amended, § 20, Strasbourg, 11 December 2017 <www.venice.coe.int/webforms/documents/default.aspx? pdffile=CDL-AD(2017)028-e $>$ accessed 12 February 2021.

European Parliament resolution of 13 April 2016 on the situation in Poland <http://www.europarl. europa.eu/sides/getDoc.do?type=TA\&reference=P8-TA-2016-0123\&language=EN $>\quad$ accessed 12 February 2021.

European Parliament resolution of 14 September 2016 on the recent developments in Poland and their impact on fundamental rights as laid down in the Charter of Fundamental Rights of the European Union <http://www.europarl.europa.eu/sides/getDoc.do?type=TA\&reference=P8-TA2016-0344\&language=EN $>$ accessed 12 February 2021.

European Parliament resolution of 15 November 2017 on the situation of the rule of law and democracy in Poland <www.europarl.europa.eu/sides/getDoc.do?type=TA\&language=EN\&refere nce=P8-TA-2017-0442> accessed 12 February 2021.

CDL-AD(2012)001-e, Opinion on Act CLXII of 2011 on the Legal Status and Remuneration of Judges and Act CLXI of 2011 on the Organisation and Administration of Courts of Hungary, adopted by the Venice Commission at its 90th Plenary Session (Venice, 16-17 March 2012) <https://www.venice. coe.int/webforms/documents/CDL-AD(2012)001-e.aspx> accessed 12 February 2021. 
European Parliament resolution of 3 July 2013 on the situation of fundamental rights: standards and practices in Hungary (pursuant to the European Parliament resolution of 16 February 2012). П. ВС. <http://www.europarl.europa.eu/sides/getDoc. do?pubRef=-//EP//TEXT+TA+P7-TA-20130315+0+DOC+XML+V0//EN> accessed 12 February 2021.

Botezatu E, Regional cooperation in Central and Southeastern Europe: the Romanian experience in fighting corruption, European Institute of Romania, October $2006<$ https://mpra.ub.uni-muenchen. de/3163/> accessed 12 February 2021.

Mendelski M, Romanian rule of law reform: A two dimensional approach (Romania under Basescu 2011) 155-179.

European Commission, EU Anti-Corruption Report, Report from the Commission to the Council and the European Parliament, Brussels, 3 February 2014 COM(2014) 38 final <https://ec.europa.eu/ home-affairs/sites/homeaffairs/files/e-library/documents/policies/organized-crime-and-humantrafficking/corruption/docs/acr_2014_en.pdf> accessed 12 February 2021.

Report from the Commission to the European parliament and the Council On Progress in Romania under the Cooperation and Verification Mechanism, Brussels, 15 November 2017 COM(2017) 751 final.

CDL-PI(2018)007, Opinion on draft amendments to Law No. 303/2004 on the statute of judges and prosecutors, Law No. 304/2004 on judicial organization, and Law No. 317/2004 on the Superior Council for Magistracy, para $161<$ <ttps://www.venice.coe.int/webforms/documents/default. aspx?pdffile=CDL-AD(2018)017-e $>$ accessed 12 February 2021.

CDL-AD(2018)017, Opinion on draft amendments to Law No 303/2004 on the statute of judges and prosecutors, Law No. 304/2004 on judicial organization, and Law No 317/2004 on the Superior Council for Magistracy, para 162 <https://www.venice.coe.int/webforms/documents/default. aspx?pdffile=CDL-AD(2018)017-e $>$ accessed 12 February 2021.

CDL-AD(2018)021, Opinion on Amendments to the Criminal Code and the Criminal Procedure Code, adopted by the Venice Commission at its 116th Plenary Session (Venice, 19-20 October 2018) $<$ https://www.venice.coe.int/webforms/documents/default.aspx?pdffile=CDL-AD(2018)021-e> accessed 12 February 2021.

CDL-AD(2019)014, Opinion on Government Emergency Ordinance 7/2019 of 20 February 2019 on amendments to the three laws of justice in Romania (CDL-REF(2019)013 <https://www.venice.coe. int/webforms/documents/default.aspx?pdffile=CDL-AD(2019)014-e $>$ accessed 12 February 2021.

Constitution of the Republic of Moldova, art. 143(2) <https://www.presedinte.md/eng/ constitution> accessed 12 February 2021.

CDL-AD(2020)015, Urgent Joint Opinion of the Venice Commission and the Directorate of Human Rights (DHR) of the Directorate Generale of Human Rights and Rule of Law (DGI) of the Council of Europe on the Draft Law on Amending the Law No 947/1996 on the Superior Council of Magistracy $<$ https://www.venice.coe.int/webforms/documents/default.aspx?pdffile=CDL-AD(2020)015> accessed 12 February 2021.

CDL-AD(2020)007, Joint Opinion of the Venice Commission and the Directorate General of Human Rights and Rule of Law (DGl) of the Council of Europe on the Revised Draft Provisions on Amending and Supplementing the Constitution with Respect to the Superior Council of Magistracy <https:// www.venice.coe.int/webforms/documents/default.aspx?pdffile=CDL-AD(2020)007-e > accessed 12 February 2021.

Law of Ukraine 'On Restoration of Confidence in the Judiciary in Ukraine' of 8 April $2014<$ https:// zakon.rada.gov.ua/laws/show/1188-18\#Text> accessed 12 February 2021.

Reports of the temporary commission <http://www.vru.gov.ua/add_text/30 > accessed 12 February 2021.

CDL-AD(2007)028, Judicial Appointments Report adopted by the Venice Commission at its 70th Plenary Session (Venice, 16-17 March 2007), Venice, 22 June $2007<$ http://www.venice.coe.int/ webforms/documents/default.aspx?pdffile=CDL-AD(2007)028-e > accessed 12 February 2021. 